\title{
Application of white mustard and oats in the phytostabilisation of soil contaminated with cadmium with the addition of cellulose and urea
}

\author{
Edyta Boros-Lajszner ${ }^{1}$ • Jadwiga Wyszkowska ${ }^{1}$ (D) $\cdot$ Jan Kucharski $^{1}$
}

Received: 17 May 2019 / Accepted: 21 September 2019 / Published online: 25 October 2019

(C) The Author(s) 2019

\begin{abstract}
Purpose Determination of the effectiveness of white mustard and oats in immobilising cadmium as a soil contaminant and determining the role of cellulose and urea in restoring homeostasis in soil under pressure from $\mathrm{Cd}^{2+}$.

Materials and methods Soil samples were contaminated with cadmium $\left(\mathrm{CdCl}_{2} \cdot 2{ }^{1} /{ }_{2} \mathrm{H}_{2} \mathrm{O}\right)$ at $0,4,8$ and $16 \mathrm{mg} \mathrm{Cd}^{2+} \mathrm{kg}^{-1}$. In order to reduce the negative impact of $\mathrm{Cd}^{2+}$, cellulose was introduced to the soil at the following rates: 0 and $15 \mathrm{~g} \mathrm{~kg}^{-1}$ and urea at 80 and $160 \mathrm{mg} \mathrm{N} \mathrm{kg}^{-1}$. The yield of the above-ground parts and roots was determined on days 40 and 80 of the experiment, along with the cadmium content in the plant material. The enzyme activity was also determined, and the physical and chemical properties of the soil were determined on the day of the oats' (aftercrop) harvest.

Results and discussion Contamination of soil with $\mathrm{Cd}^{2+}$ at 4 to $16 \mathrm{mg} \mathrm{kg}^{-1} \mathrm{~d} . \mathrm{m}$. of soil reduced the yield of white mustard and oats. The tolerance index (TI) values indicate that oats (aftercrop) is more tolerant than white mustard of soil contamination with $\mathrm{Cd}^{2+}$. Cadmium accumulated more intensely in roots compared with the above-ground parts of the plants. The translocation index (TF) indicates smaller $\mathrm{Cd}^{2+}$ translocation from roots to above-ground parts, as it was below 1 in both plants. An addition of cellulose and nitrogen offsets the adverse impact of cadmium on plants. Arylsulphatase was the most sensitive to soil contamination with $\mathrm{Cd}^{2+}$, followed by dehydrogenases, catalase, $\beta$-glucosidase and urease, and alkaline phosphatase and acid phosphatase were the least sensitive. Contamination of soil with $\mathrm{Cd}^{2+}$ changed its physical and chemical properties only slightly.

Conclusions White mustard and oats have phytostabilisation potential with respect to soil contaminated with cadmium. Cellulose introduced to the soil and fertilisation with urea alleviated the negative impact of cadmium on the growth and development of plants.
\end{abstract}

Keywords $\mathrm{Cd}^{2+} \cdot$ Physical and chemical properties $\cdot$ Plant yield $\cdot$ Tolerance index (TI) $\cdot$ Translocation factor (TF) $\cdot$ Soil enzymes

\section{Introduction}

Cadmium is a common element in the earth's crust. Although from a chemical point of view, it is similar to zinc; unlike zinc, cadmium is not biologically essential. The use of cadmium in industry (e.g. for the production of car batteries, fluorescent materials, rubber, paint, pigments, nickel-cadmium batteries) and the development of civilisation and urbanisation may lead

Responsible editor: Dong-Mei Zhou

Jadwiga Wyszkowska

jadwiga.wyszkowska@uwm.edu.pl

1 Department of Microbiology, University of Warmia and Mazury in Olsztyn, Plac Łódzki 3, 10-727 Olsztyn, Poland to the significant exposure of the natural environment to contamination with cadmium (Satarug et al. 2010). Cadmium salts are relatively soluble, which is why this element can migrate in the natural environment. Moreover, cadmium forms soluble complexes with organic compounds, which increases its mobility (Prica et al. 2012; Lorenc-Plucińska et al. 2013; Aghababaei et al. 2014). Therefore, solutions are being sought to counteract these processes. Areas contaminated with heavy metals require decontamination action. Therefore, phytoremediation may be one of the measures taken in such areas. It is not costly and it has no negative impact on the environment (Roccotiello et al. 2010; Cheraghi et al. 2011). Phytostabilisation, i.e. the ability of plants to take up, store and immobilise heavy metals by binding them to bioactive molecules, is one of the methods of phytoremediation (SasNowosielska et al. 2008; Cheraghi et al. 2011; Dalvi and 
Bhalerao 2013). The mechanism of immobilisation involves prevention of metal ion transport across the cellular membrane and their inactivation by binding within the cell or modification to less toxic species. Interception of toxic heavy metal ions in plant cell cytosol and their transport is mediated by polypeptides rich in - $\mathrm{SH}$ groups, such as phytochelatins, metallothioneins and glutathione. Transport of metals bound in complexes along the tonoplast to the vacuoles is mediated mainly by the metal $/ \mathrm{H}^{+}$antiport or the ABC transporter (ATPbindingcassette), or the ZIP transporter family (iron-, zincregulated transporter-likeproteins). Heavy metals are immobilised in the tonoplast by their binding to organic acids (mugineic acid, phytic acid) or to sulphides (Kabata-Pendias and Mukherjee 2007; Wu et al. 2010; Dalvi and Bhalerao 2013). Phytostabilisation can be boosted by applying heavy metal immobilising additives to soil. Such additives introduced to the soil may include inorganic or organic substances which increase the soil $\mathrm{pH}$, enhance the heavy metal binding effect, decrease bioavailability and toxicity by complex formation or metal precipitation, and increase the organic matter content and the ability to retain water (Masto et al. 2008; Mench et al. 2010; Gómez-Sagasti et al. 2012; Burns et al. 2013; Bolan et al. 2014). A significant element in the phytostabilisation process is the selection of suitable plant species. Such plants should be characterised by tolerance to high cadmium soil contamination, the ability to form a compact plant cover on a soil surface, have a well-developed root system, increased accumulation of cadmium in the roots, and low nutritional and habitat requirements (Mench et al. 2010; Zou et al. 2012). Grasses exhibiting most of the above properties are most frequently used in heavy-metal phytostabilisation. Moreover, some crops such as wheat, oats, maize and white mustard are used in phytoremediation (Knox et al. 2001; Yoon et al. 2006; Zhang et al. 2010). Therefore, a study was conducted aimed at determining the effectiveness of white mustard and oats in immobilising cadmium as a soil contaminant. Additionally, nitrogen and cellulose was introduced to the soil to support phytostabilisation. Cellulose is a polysaccharide and the main component of the plant cell wall structure. Post-harvest plant residues in soil contain approx. $45 \%$ of cellulose. To achieve intensive cellulose decomposition in soil by microorganisms, appropriate requirements must be met (the $\mathrm{C} / \mathrm{N}$ ratio, water content in the soil, soil $\mathrm{pH}$ ). An adequate amount of nitrogen should be supplied to the soil to ensure a desired $\mathrm{C} / \mathrm{N}$ ratio. Following the introduction of cellulose into the soil, the availability of carbon is in abundance. Under such conditions, microorganisms multiply and reduce the mineral nitrogen pool, while the deficiency in mineral nitrogen retards cellulose transformation (Haddad et al. 2019). In order to determine the condition of soil contaminated with cadmium, activity of dehydrogenases, catalase, urease, acid phosphatase, alkaline phosphatase, $\beta$-glucosidase and arylsulphatase, and the physical and chemical properties of soil were determined in the soil samples. Since cadmium has a negative impact on the soil microbiome, a study hypothesis was put forward that plants can reduce the adverse effect of cadmium on soil biological properties by 'trapping' the metal in their roots and above-ground parts. Cellulose and nitrogen were additionally introduced to the soil to support the plants in it.

\section{Materials and methods}

\subsection{Study area characterisation}

The land used for the study is situated in Tomaszkowo near Olsztyn in the Voivodship of Warmia and Mazury in the northeast of Poland, central Europe $\left(53.7161^{\circ} \mathrm{N}, 20.4167^{\circ} \mathrm{E}\right)$. The soil for analyses was collected from the 0-20-cm layer. It was subsequently dried at room temperature and sieved through a 1-cm mesh sieve. In terms of granulation, it was classified as sandy clay loam; detailed characteristics are included in Table 1.

\subsection{Pot experiment}

The experiment was carried out in the vegetation hall of the University of Warmia and Mazury, Olsztyn, in north-eastern Poland. Soil was placed in 3.5-kg pots; earlier, cadmium chloride was added to the soil at 4,8 and $16 \mathrm{mg} \mathrm{Cd}^{2+} \mathrm{kg}^{-1}$, cellulose at $15 \mathrm{~g} \mathrm{~kg}^{-1}$, and urea at 80 and $160 \mathrm{mg} \mathrm{N} \mathrm{kg}^{-1}$. Pots with soil uncontaminated with cadmium and without cellulose addition were control objects. Fertilisation was also applied: $\mathrm{N}$

Table 1 Physicochemical properties of the soils used in the experiment

\begin{tabular}{|c|c|c|c|c|c|c|c|c|c|c|}
\hline \multirow[t]{2}{*}{ Type of soil } & \multicolumn{3}{|c|}{ Granulometric composition (w mm) } & \multirow{2}{*}{$\begin{array}{l}\mathrm{C}_{\text {org }} \\
\mathrm{g} \mathrm{kg}^{-1}\end{array}$} & \multirow[t]{2}{*}{$\mathrm{N}_{\text {total }}$} & \multirow[t]{2}{*}{$\mathrm{pH}_{\mathrm{KCl}}$} & \multirow{2}{*}{\multicolumn{2}{|c|}{$\begin{array}{l}\text { HAC } \quad \text { EBC } \\
\left(\mathrm{mmol}^{(+)} \mathrm{kg}^{-1} \text { soil }\right)\end{array}$}} & \multirow[t]{2}{*}{ CEC } & \multirow[t]{2}{*}{$\mathrm{BS}(\%)$} \\
\hline & $\begin{array}{l}<0.002 \\
\%\end{array}$ & $\begin{array}{l}0.002- \\
0.050\end{array}$ & $\begin{array}{l}0.050- \\
2.000\end{array}$ & & & & & & & \\
\hline $\mathrm{scl}$ & 1.49 & 17.95 & 80.56 & 14.30 & 0.98 & 7.00 & 6.40 & 165.90 & 172.30 & 96.29 \\
\hline
\end{tabular}

$s c l$ sandy clay loam, $C_{\text {org }}$ total organic carbon, $N_{\text {total }}$ total nitrogen, $H A C$ hydrolytic acidity, $E B C$ total exchangeable cations, $C E C$ total exchange capacity of soil, $B S$ basic cations saturation ratio in soil 


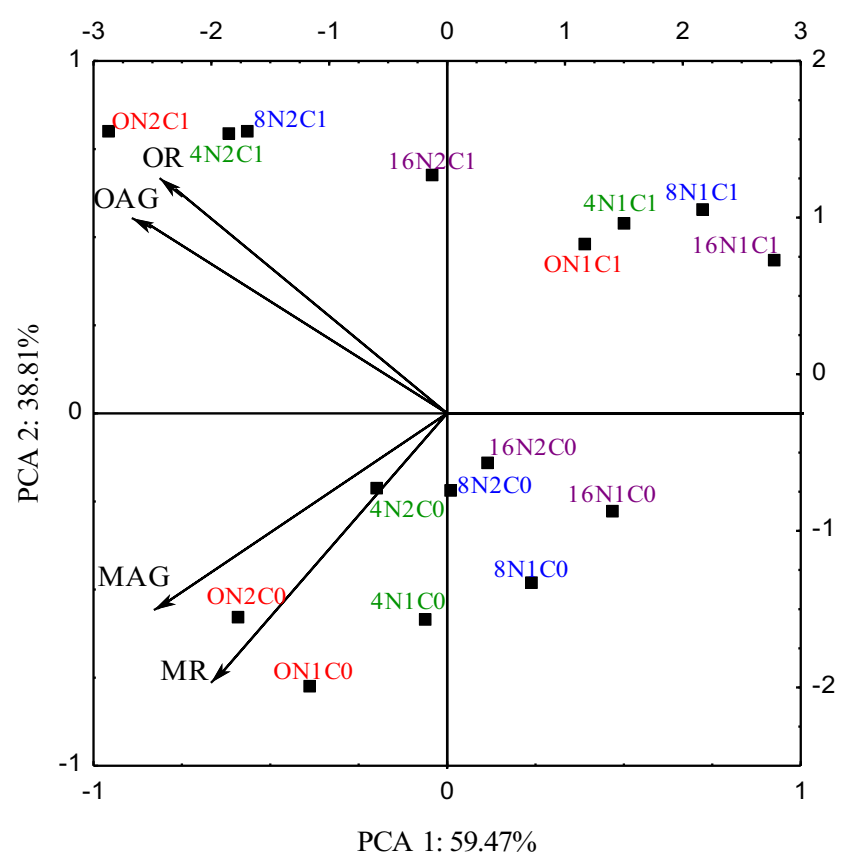

Fig. 1 Principal component analysis (PCA) of plant yield in soil contaminated with cadmium. Dose $\mathrm{Cd}^{2+} \mathrm{mg} \mathrm{kg}^{-1}$ d.m. of soil: $0-0 \mathrm{mg}, 4-4 \mathrm{mg}$, 8-8 mg and 16-16 mg. Cellulose: $\mathrm{C} 0$ without cellulose, $\mathrm{C} 1$ with cellulose. Dose $\mathrm{N} \mathrm{mg} \mathrm{kg}^{-1}$ d.m. of soil: N1-80 mg; N2-160 mg. Plant species: $\mathrm{M}$ white mustard, $\mathrm{O}$ oat. Plant parts: AG above-ground parts, $\mathrm{R}$ roots. - indicates variables; - - indicates cases

80 and $160 \mathrm{mg}\left[\mathrm{CO}\left(\mathrm{NH}_{2}\right)_{2}\right]$, P $21 \mathrm{mg}\left[\mathrm{KH}_{2} \mathrm{PO}_{4}\right], \mathrm{K} 73 \mathrm{mg}$ $\left[\mathrm{KH}_{2} \mathrm{PO}_{4}+\mathrm{KCl}\right]$, and $\mathrm{Mg} 15 \mathrm{mg}\left[\mathrm{MgSO}_{4} \cdot 7 \mathrm{H}_{2} \mathrm{O}\right]$. The first nitrogen dose was adjusted to suit the plants' nutritional requirements. Being the simplest organic substance in terms of molecular structure, cellulose was used in the experiment as an additional source of carbon for microorganisms. The content of total organic carbon and total nitrogen was taken into account when establishing the cellulose and nitrogen rate. The soil was subsequently mixed thoroughly and placed in the

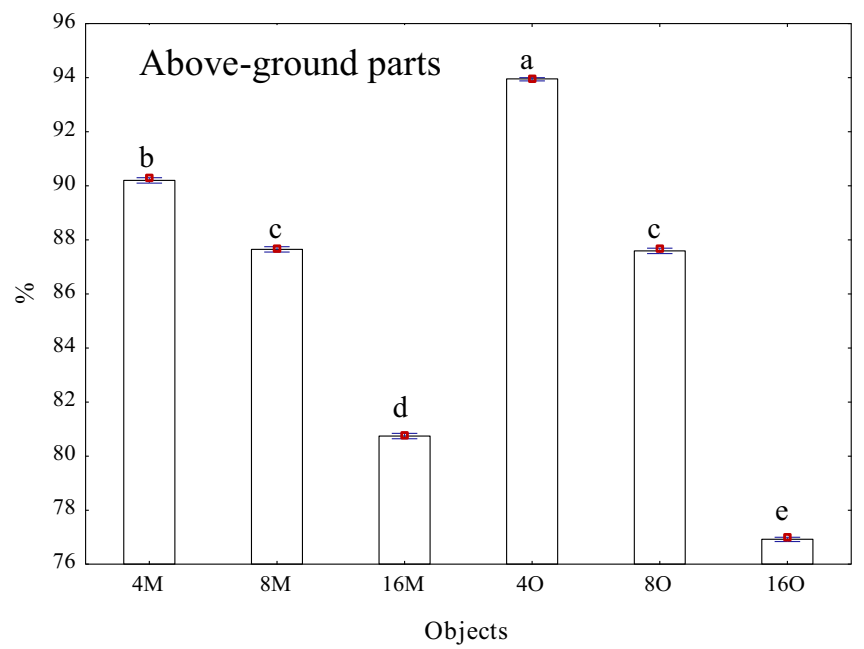

Fig. 2 Percentage reduction of the above-ground parts and roots of plants, regardless of cellulose addition and nitrogen rate, $n=3$. Dose $\mathrm{Cd}^{2+} \mathrm{mg} \mathrm{kg}{ }^{-1}$ d.m. of soil: $0-0 \mathrm{mg}, 4-4 \mathrm{mg}, 8-8 \mathrm{mg}$ and $16-16 \mathrm{mg}$. pots. Twenty seeds of white mustard (Sinapis alba) var. Rota were sown. After germination, the plant number was reduced to eight per pot. After 40 days, above-ground parts and roots were harvested, and oats (Avena sativa $\mathrm{L}$ ) var. Bingo was sown as the aftercrop. After germination, the number of plants was reduced to 12 per pot and they were harvested after another 40 days. The soil moisture content was maintained at $50 \%$ of the capillary water capacity to ensure the proper growth and development of the plants. The experiment was performed in four replicates.

\subsection{Characteristics of cellulose and urea}

The cellulose tested in the study was obtained from ACROS ORGANICS. It was extra pure cellulose, with a particle size of $90 \mu \mathrm{m}$. The nitrogen was introduced to the soil as analytically pure urea $\mathrm{CH}_{4} \mathrm{H}_{2} \mathrm{O}$ which had been obtained from the P.P.H 'STANLAB', Poland.

\subsection{Methodology of determination of the soil physical and chemical properties and cadmium level in plants}

Activity of the following soil enzymes was determined in soil samples after harvesting white mustard (day 40) and oats (day 80):

- Dehydrogenase ( $\mu$ mol TFF kg-1 d.m. $\mathrm{h}^{-1}$ of soil)

- Catalase ( $\mathrm{mol} \mathrm{O}_{2} \mathrm{~kg}^{-1}$ d.m. $\mathrm{h}^{-1}$ of soil)

- Urease (mmol N-NH $\mathrm{kg}^{-1}$ d.m. $\mathrm{h}^{-1}$ of soil)

- Acid phosphatase (mmol PNP kg ${ }^{-1}$ d.m. $\mathrm{h}^{-1}$ of soil)

- Alkaline phosphatase (mmol PNP kg ${ }^{-1}$ d.m. $\mathrm{h}^{-1}$ of soil)

- $\quad \beta$-Glucosidase (mmol PNP kg-1 d.m. $\mathrm{h}^{-1}$ of soil)

- Arylsulphatase (mmol PNP kg${ }^{-1}$ d.m. $\mathrm{h}^{-1}$ of soil)

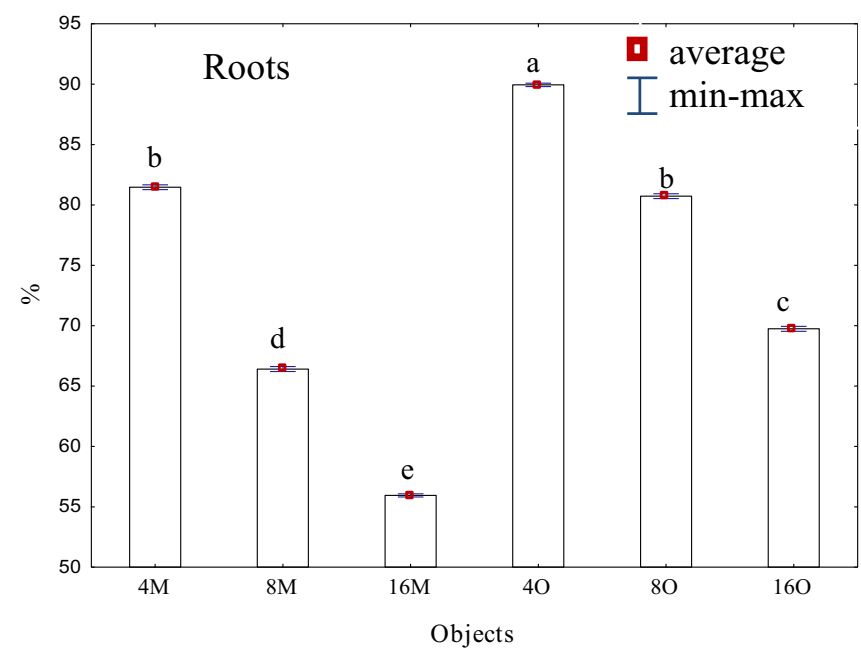

Plant species: $\mathrm{M}$ white mustard, $\mathrm{O}$ oat. The same letters (a-e) are assigned to the same homogeneous groups 

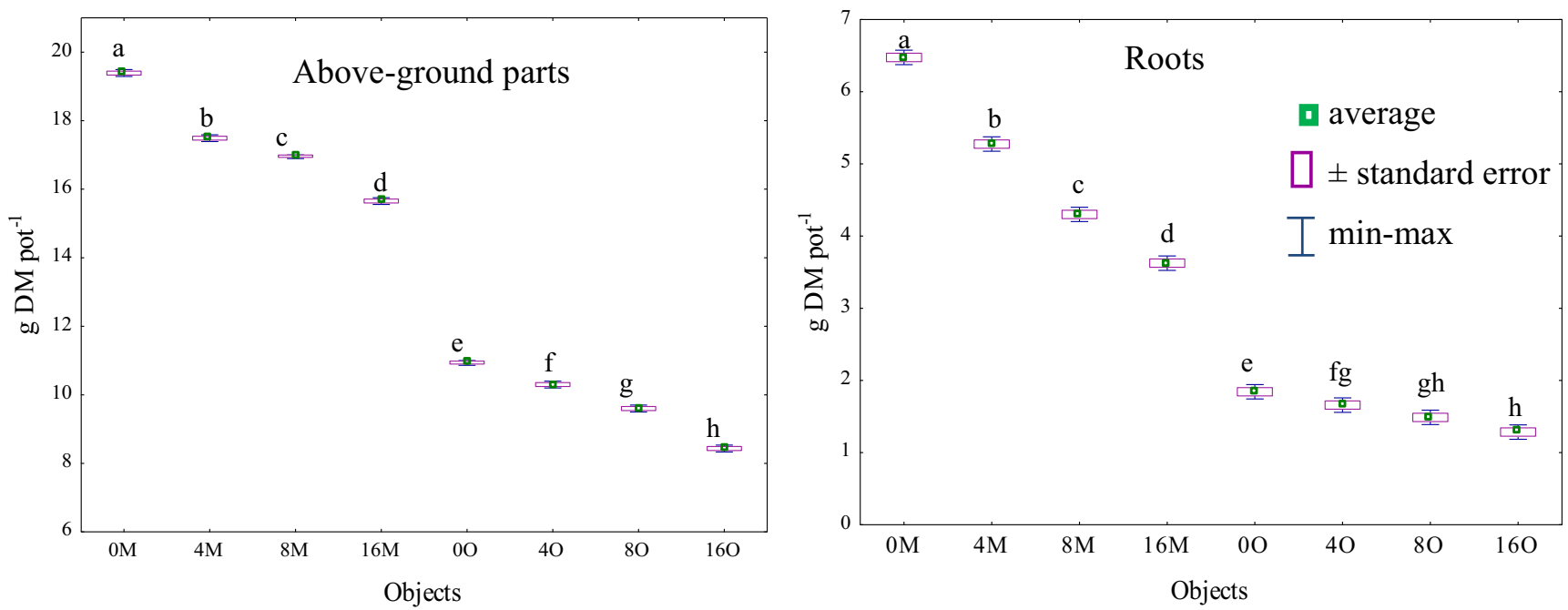

Fig. 3 Effect of soil contamination with cadmium on plant yield, regardless of cellulose addition and nitrogen rate, $n=3 . \mathrm{Dose} \mathrm{Cd}^{2+} \mathrm{mg} \mathrm{kg}{ }^{-1} \mathrm{~d} . \mathrm{m} . \mathrm{of}_{\mathrm{soil}}$ : 0-0 mg, 4-4 mg, 8-8 mg and 16-16 mg. Plant species: M white mustard, $O$ oat. The same letters $(\mathrm{a}-\mathrm{h})$ are assigned to the same homogeneous groups

The detailed procedures by which the activity of these enzymes is determined are described by Boros-Lajszner et al. (2018).

The following physical and chemical properties of soil were determined after harvesting oats (aftercrop):

- $\mathrm{pH}$ of the soil, total organic carbon, hydrolytic acidity, total exchangeable base cations, total cation exchange capacity of soil and soil saturation with base cations. The detailed procedures by which these determinations were made are described by Boros-Lajszner et al. (2018).

- Cadmium content in above-ground parts and roots was determined by atomic absorption spectroscopy (AAS) after microwave mineralisation as per the standard PN-EN 14084:2004 (N).

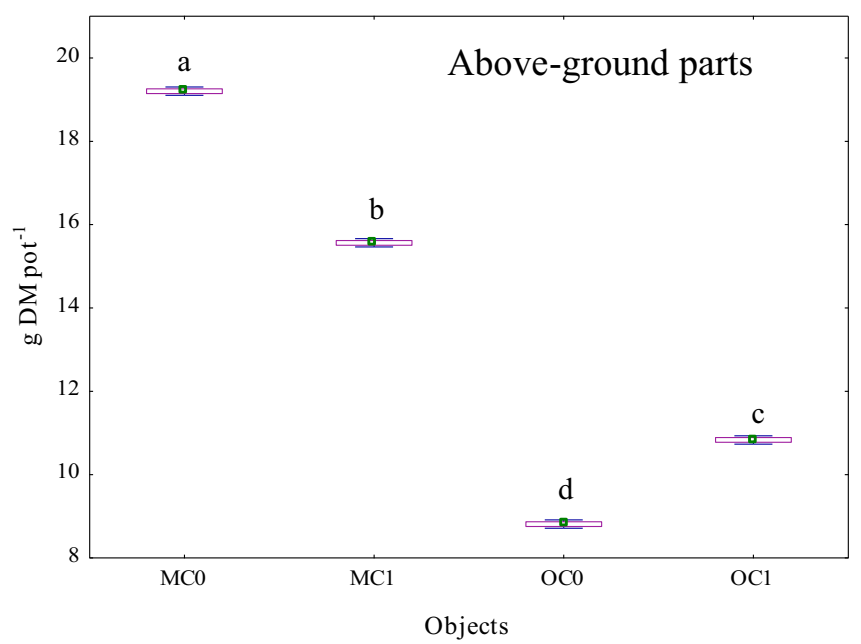

\subsection{Calculations and statistical analysis}

The tolerance of white mustard and oats to an excess of $\mathrm{Cd}^{2+}$ was compared using a tolerance index, denoted as TI. It was calculated as the ratio of the plant yield from contaminated soil to the plant yield from non-contaminated soil (control).

They were calculated from the following formula:

$$
\mathrm{TI}=\frac{Y_{\mathrm{Cd}}}{Y_{\mathrm{C}}}
$$

where:

$Y_{\mathrm{Cd}}$ mean plant yield from soil contaminated with $\mathrm{Cd}^{2+}$ $Y_{\mathrm{C}}$ mean plant yield from soil non-contaminated with $\mathrm{Cd}^{2+}$

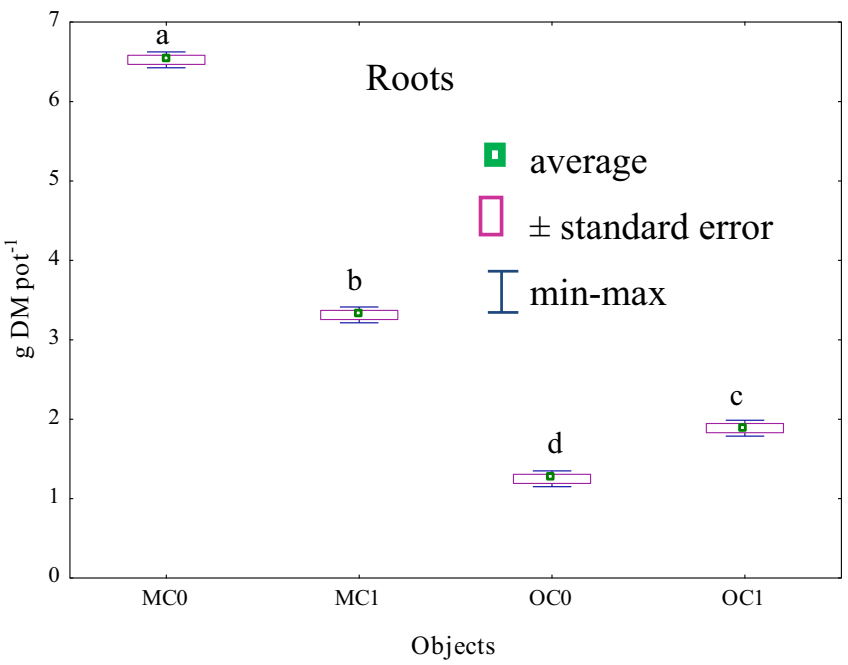

Fig. 4 Effect of cellulose addition on plant yield, regardless of cadmium and nitrogen rate, $n=3$. Cellulose: $\mathrm{C} 0$ without cellulose; $\mathrm{C} 1$ with cellulose. Plant species: $\mathrm{M}$ white mustard, $\mathrm{O}$ oat. The same letters $(\mathrm{a}-\mathrm{d})$ are assigned to the same homogeneous groups 

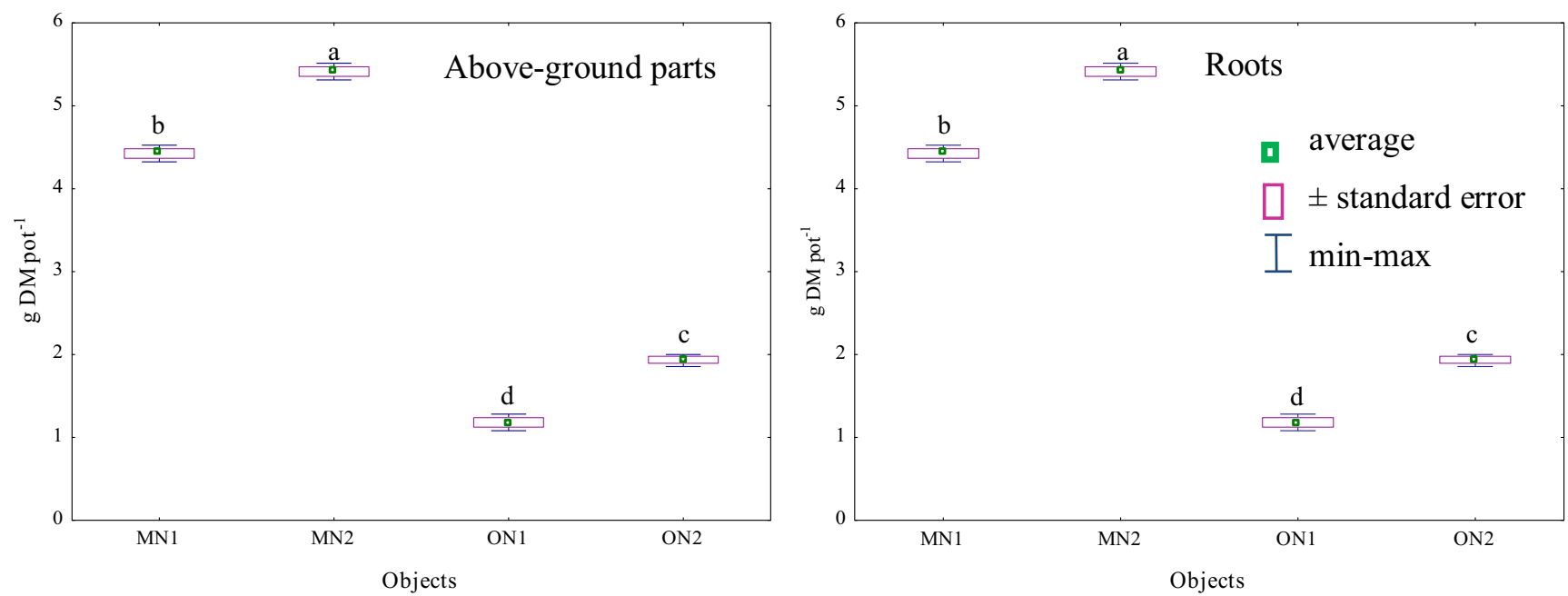

Fig. 5 Effect of nitrogen rate on plant yield, regardless of cadmium rate and cellulose addition, $n=3$. Dose N mg kg ${ }^{-1}$ d.m. of soil: N1-80 mg and N2$160 \mathrm{mg}$. Plant species: $\mathrm{M}$ white mustard, $\mathrm{O}$ oat. The same letters $(\mathrm{a}-\mathrm{d})$ are assigned to the same homogeneous groups

The following was calculated from cadmium content in the above-ground parts and roots:

$$
\mathrm{TF}=\frac{\mathrm{Cd}_{\mathrm{AG}}}{\mathrm{Cd}_{\mathrm{R}}}
$$

where:

$\mathrm{Cd}_{\mathrm{AG}}$ cadmium content in the above-ground parts of plants

$\mathrm{Cd}_{\mathrm{R}}$ cadmium content in the plant roots

The most important phytoremediation parameter is the tolerance factor (TF), whose value for plants should not exceed 1. Low values of this parameter reflect a poorly functioning system of cadmium transport from the roots to the aboveground parts.

STATISTICA 13.1 software (StatSoft 2018) was used to analyse the results statistically with the analysis of variance ANOVA at $P \leq 0.05$. Homogeneous groups were determined with the Tukey test. The above-ground and root yield is shown using principal component analysis (PCA).

\section{Results}

\subsection{Plant growing}

The phytotoxicity of cadmium, which showed as a decrease in the biomass yield, varied depending on the plant species and the level of soil contamination with the metal. The plants reacted to $\mathrm{Cd}^{2+}$ by reducing both the above-ground and root biomass (Fig. 1). The principal components explain a total of $98.28 \%$ of the variance of the primary variables; PCA 1 explains $59.47 \%$ and PCA $238.81 \%$. It was observed that two homogeneous groups were formed around the principal components. The first group is made up of vectors representing the above-ground parts and the root yield of white mustard and others consisting of the above-ground parts and the root yield of oats. Vectors deployed along the coordinate axes indicate that there is a negative impact of cadmium on the plant yield, despite the application of cellulose and nitrogen. Biomass of

Table 2 Tolerance index (TI) based on plant yield

\begin{tabular}{|c|c|c|c|c|}
\hline \multirow[t]{4}{*}{ Plant parts } & \multicolumn{4}{|l|}{ Plant species } \\
\hline & \multicolumn{2}{|l|}{ White mustard } & \multicolumn{2}{|l|}{ Oat } \\
\hline & \multicolumn{4}{|c|}{ Dose of nitrogen $\left(\mathrm{mg} \mathrm{kg}^{-1}\right)$} \\
\hline & $\mathrm{N}_{80}$ & $\mathrm{~N}_{160}$ & $\mathrm{~N}_{80}$ & $\mathrm{~N}_{160}$ \\
\hline \multicolumn{5}{|l|}{ Without cellulose } \\
\hline Above-ground parts & $0.827^{\mathrm{b}} \pm 1.253$ & $0.817^{\mathrm{b}} \pm 0.564$ & $0.872^{\mathrm{b}} \pm 0.633$ & $0.879^{\mathrm{a}} \pm 0.743$ \\
\hline Roots & $0.690^{\mathrm{d}} \pm 1.202$ & $0.703^{c} \pm 0.143$ & $0.695^{\mathrm{d}} \pm 0.452$ & $0.848^{\mathrm{b}} \pm 0.222$ \\
\hline \multicolumn{5}{|l|}{ With cellulose } \\
\hline Above-ground parts & $0.874^{\mathrm{a}} \pm 0.611$ & $0.947^{\mathrm{a}} \pm 0.412$ & $0.883^{\mathrm{a}} \pm 0.844$ & $0.832^{\mathrm{c}} \pm 1.532$ \\
\hline Roots & $0.701^{\mathrm{c}} \pm 0.504$ & $0.623^{d} \pm 0.123$ & $0.807^{\mathrm{c}} \pm 0.651$ & $0.825^{\mathrm{d}} \pm 0.191$ \\
\hline
\end{tabular}

The same letters (a-d) in columns are assigned to the same homogeneous groups, $n=3$ 
Table 3 Cadmium content ( $\mathrm{mg} \mathrm{kg}^{-1}$ d.m.) in above-ground parts and roots of plants and translocation factor (TF)

\begin{tabular}{|c|c|c|c|}
\hline Dose $\mathrm{Cd}^{2+}\left(\mathrm{mg} \mathrm{kg}^{-1}\right.$ of soil) & Above-ground parts & Roots & $\mathrm{TF}$ \\
\hline \multicolumn{4}{|l|}{ White mustard } \\
\hline \multicolumn{4}{|l|}{ Without cellulose } \\
\hline 0 & $0.770^{\mathrm{e}} \pm 0.101$ & $5.137^{\mathrm{f}} \pm 0.671$ & $0.150^{\mathrm{d}} \pm 0.012$ \\
\hline 16 & $22.503^{\mathrm{a}} \pm 2.433$ & $54.881^{\mathrm{b}} \pm 7.682$ & $0.410^{\mathrm{a}} \pm 0.011$ \\
\hline \multicolumn{4}{|l|}{ With cellulose } \\
\hline 0 & $0.449^{\mathrm{f}} \pm 0.062$ & $1.371^{\mathrm{g}} \pm 0.192$ & $0.327^{\mathrm{b}} \pm 0.013$ \\
\hline 16 & $11.407^{\mathrm{b}} \pm 1.363$ & $43.690^{\mathrm{c}} \pm 6.733$ & $0.261^{\mathrm{c}} \pm 0.012$ \\
\hline \multicolumn{4}{|l|}{ Oat } \\
\hline \multicolumn{4}{|l|}{ Without cellulose } \\
\hline 0 & $0.073^{\mathrm{h}} \pm 0.014$ & $0.652^{\mathrm{h}} \pm 0.093$ & $0.112^{\mathrm{e}} \pm 0.013$ \\
\hline 16 & $5.719^{\mathrm{c}} \pm 0.563$ & $79.119^{\mathrm{a}} \pm 8.511$ & $0.072^{\mathrm{h}} \pm 0.014$ \\
\hline \multicolumn{4}{|l|}{ With cellulose } \\
\hline 0 & $0.185^{\mathrm{g}} \pm 0.033$ & $5.590^{\mathrm{e}} \pm 0.662$ & $0.033^{\mathrm{i}} \pm 0.011$ \\
\hline 16 & $3.446^{\mathrm{d}} \pm 0.152$ & $34.338^{\mathrm{d}} \pm 5.731$ & $0.100^{\mathrm{fg}} \pm 0.013$ \\
\hline
\end{tabular}

The same letters $(\mathrm{a}-\mathrm{i})$ in columns are assigned to the same homogeneous groups, $n=3$

the above-ground parts of the plants under study decreased compared to the control with increasing heavy metal content in soil. Reduction of the above-ground biomass of white mustard and oats was similar. White mustard biomass decreased significantly by $10 \%, 12 \%$ and $19 \%$ for 4,8 and $16 \mathrm{mg} \mathrm{Cd}^{2+}$ $\mathrm{kg}^{-1}$ of soil, regardless of the addition of cellulose and nitrogen as urea (Fig. 2). Biomass of the oats' above-ground parts decreased by $6 \%, 12 \%$ and $23 \%$. The root biomass decreased to a greater extent than the above-ground parts for all plants under study. The greatest yield reduction was observed for white mustard. The biomass of white mustard roots decreased significantly by $19 \%\left(-4 \mathrm{mg} \mathrm{Cd}^{+2} \mathrm{~kg}^{-1}\right)$, by $34 \%\left(-8 \mathrm{mg} \mathrm{Cd}^{+}\right.$ ${ }^{2} \mathrm{~kg}^{-1}$ ) and by $44 \%\left(-16 \mathrm{mg} \mathrm{Cd}^{+2} \mathrm{~kg}^{-1}\right)$ compared to the control, respectively. The respective values for oats as the aftercrop were the following: $10 \%, 19 \%$ and $30 \%$. Figure 3 presents the effect of soil contamination with cadmium on the plant yield, which illustrates how increasing metal doses decreased the above-ground parts and roots' biomass of white mustard and oats, regardless of the addition of cellulose or nitrogen. This was particularly manifested in the case of roots. Cellulose introduced to the soil alleviated the negative impact of the heavy metal on the growth and development of oats (aftercrop), as the yield of the above-ground parts and roots in pots with an addition of cellulose was higher by $19 \%$ and $34 \%$ compared to the pots without the sorbent addition. It was the reverse in pots with white mustard, because the yield of above-ground parts and roots was higher in the pots without an addition of cellulose by $19 \%$ and $33 \%$, respectively (Fig. 4). The application of nitrogen in two rates, i.e. 80 and $160 \mathrm{mg} \mathrm{N} \mathrm{kg}$, was also important, as a higher yield of the above-ground parts of white mustard (by 16\%) and oats (by $33 \%$ ) was observed, and that of roots (by $20 \%$ and $50 \%$, respectively) in pots with a higher nitrogen rate compared to pots in which $80 \mathrm{mg} \mathrm{N} \mathrm{kg}^{-1}$ was applied (Fig. 5). The tolerance index (TI) values indicate that oats (aftercrop) were more tolerant than white mustard of soil contaminated with $\mathrm{Cd}^{2+}$. They ranged from 0.695 to 0.883 for oats, and from 0.623 to 0.874 for white mustard, except the pot with the addition of cellulose and nitrogen at $160 \mathrm{mg} \mathrm{N} \mathrm{kg}^{-1}$, where the TI was calculated as 0.947 (Table 2).

\subsection{Cadmium content evaluation}

The cadmium content in the above-ground parts and roots of white mustard and oats increased with the heavy metal rate (Table 3). More $\mathrm{Cd}^{2+}$ accumulated in the above-ground parts and roots of the plants in pots without the addition of cellulose than with an addition. Irrespective of the cellulose addition and cadmium contamination, more of this metal accumulated in pots with oats than with white mustard. More cadmium was accumulated in roots than in above-ground parts of the plants, regardless of the plant or cellulose addition.

The metal mobility in white mustard and oats was determined by means of the translocation factor (TF), which was calculated from cadmium content in the above-ground parts and roots of the plants (Table 3). For white mustard, it was higher by $36 \%$ in pots without cellulose with the cadmium rate of $16 \mathrm{mg} \mathrm{kg}^{-1}$ compared to the pots with cellulose. It was the reverse in pots with oats. This indicates an increase in the heavy metal mobility from roots to the above-ground parts caused by the cellulose application. Higher values of TF were

Fig. 6 Activity of enzymes in soil contaminated with cadmium, $n=3$. M white mustard, $\mathrm{O}$ oat, $\mathrm{C}$ control soil, Cel cellulose, N1 nitrogen dose $80 \mathrm{mg} \mathrm{kg}^{-1}$ d.m. of soil, $\mathrm{N} 2$ nitrogen dose $160 \mathrm{mg} \mathrm{kg}{ }^{-1}$ d.m. of soil. The same letters $(\mathrm{a}-\mathrm{h})$ are assigned to the same homogeneous groups 

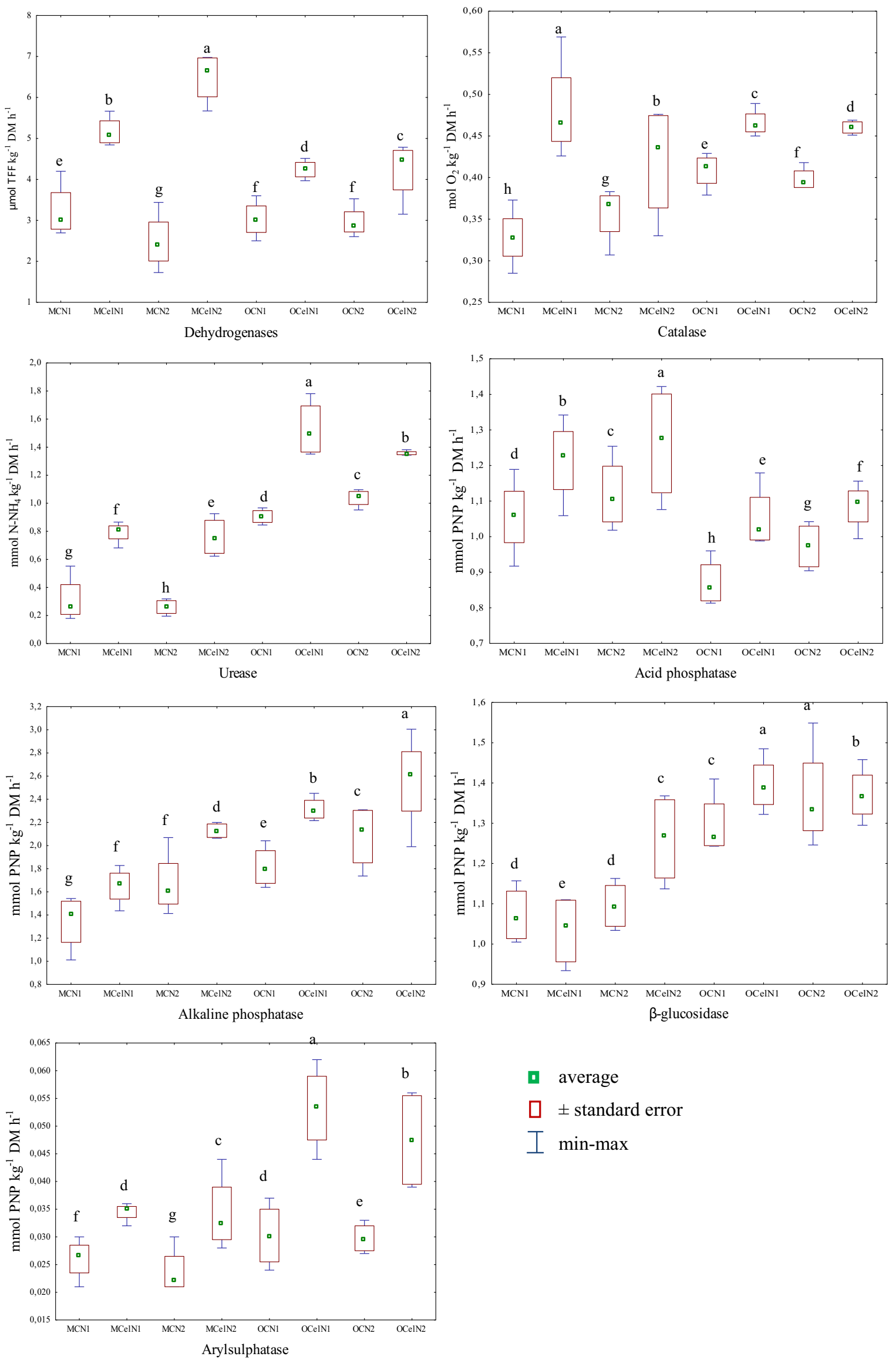
I average
$\square \pm$ standard error
I min-max 
observed in pots with white mustard than in those with oats. This may be attributed to the fact that oats were the aftercrop. The translocation factor was $<1$, and it was much lower for oats than for white mustard.

\subsection{Enzymatic assays}

Cadmium changed the biochemical properties of the soil throughout the experiment, decreasing the activity of the enzymes under study (Fig. 6). The highest cadmium rate (16 mg $\mathrm{Cd}^{2+} \mathrm{kg}^{-1}$ ) decreased the activity of arylsulphatase by $28 \%$, dehydrogenases by $26 \%$, catalase by $25 \%, \beta$-glucosidase by $23 \%$, urease by $19 \%$, acid phosphatase by $13 \%$ and alkaline phosphatase by $6 \%$ compared to the control, regardless of the plant and the nitrogen rate. The addition of cellulose to the soil improved the soil biochemical properties. It was particularly manifested in soil non-contaminated with cadmium. The effect of cellulose added to the soil on the activity of dehydrogenases, catalase and acid phosphatase was more manifested in pots with white mustard than in those with oats as the aftercrop. It was the reverse in the case of the other enzymes, i.e. the enzyme activity was higher in soil in which oats grew. Nitrogen fertilisation had no effect on the enzyme activity. In general, higher activity of dehydrogenases, catalase, urease and acid phosphatase was observed in soil with white mustard growing in it than in soil with oats, and the activity of alkaline phosphatase, $\beta$-glucosidase and arylsulphatase was higher in soil with oats growing in it, regardless of the level of soil contamination with cadmium.

\subsection{Soil physicochemical investigations}

Physicochemical properties of soil contaminated with increasing doses of cadmium are shown in Table 4. The soil $\mathrm{pH}$ changed only slightly with increasing cadmium contamination, regardless of the cellulose and nitrogen addition. The content of organic carbon in pots with cellulose was higher by ca. $5 \%$ compared to pots without cellulose, regardless of the nitrogen rate. Total exchangeable base cations also decreased with increasing contamination with the heavy metal. It was higher in pots with cellulose, particularly in those with the lower nitrogen rate (from 122.45 to $127.50 \mathrm{mmol}^{(+)} \mathrm{kg}^{-1}$ d.m. of soil). Hydrolytic acidity increased with increasing level of soil contamination with cadmium. As with total exchangeable base cations, hydrolytic acidity was higher by $33 \%$ in pots with cellulose and $80 \mathrm{mg} \mathrm{N} \mathrm{kg}^{-1}$ compared to pots without cellulose. Hydrolytic acidity and total exchangeable base cations were used to calculate the total cation exchange capacity of soil (CEC) and soil saturation with base cations (BS). These parameters decreased with increasing contamination with $\mathrm{Cd}^{2+}$. Higher values of CEC were observed in pots with cellulose compared to those without it. It was the reverse for BS.

\section{Discussion}

\subsection{Plants}

Higher plants have developed the ability to absorb and neutralise heavy metals (Rascio and Navari-Izzo 2011; Zheng et al. 2011). The literature (McGrath and Zhao 2003; Ali et al. 2013; Dalvi and Bhalerao 2013) describes two methods employed by plants to cope with such contaminants. In one of them, the absorption of heavy metals is blocked by roots. The other is the opposite of the first one, as it involves taking up, storing and immobilising heavy metals by binding them to bioactive molecules. The latest research focuses on the latter method of heavy metal neutralisation, including cadmium, by growing white mustard and oats as an aftercrop. The study has shown that oats are more tolerant of soil contamination with $\mathrm{Cd}^{2+}$ compared to white mustard. Rascio and Navari-Izzo (2011), and Zheng et al. (2011) report that there are plant species which are more tolerant of soil contamination with cadmium and which do not exhibit any symptoms of toxicity. This may result from the formation of phytochelatins, i.e. proteins which neutralise cadmium phytotoxicity by its binding. Studies conducted by these authors have shown that more cadmium is accumulated in roots than in the above-ground parts of plants. According to Masarovicova et al. (2010), this may be attributed to the fact that cadmium transport from the underground to above-ground parts was, to some extent, inhibited as a result of triggering the mechanisms of defence against stress caused by an excess of cadmium in the soil. Calculated in this study, TF indicates that white mustard and oats have the potential for phytostabilisation, as plants with low translocation factor $(\mathrm{TF}<1)$ are suitable for phytostabilisation (Roccotiello et al. 2010; Cheraghi et al. 2011). Padmavathiamma and Li (2007) found that plants which can be used for phytostabilisation must be characterised by a low translocation factor, which was confirmed in a study by the authors of this paper. In the process of phytostabilisation, cadmium is accumulated in plant roots, adsorbed on their surface and precipitates in the rhizosphere area. In this way, the negative effect of cadmium on soil is reduced. Immobilisation of heavy metals may also be enhanced by an addition of organic matter, clay minerals, carbonates or phosphates to the soil as well as by a decrease in soil acidification (Schnoor 2000; Jabeen et al. 2009). In this study, cellulose alleviated the negative impact of $\mathrm{Cd}^{2+}$ on the growth and development of white mustard and oats. It reduced the cadmium content in the above-ground parts and roots of the plants. Although a positive effect of cellulose was observed by these authors, according to literature reports (O'Connell et al. 2008; Sud et al. 2008; Hashim et al. 2011), non-modified cellulose has a low capacity for heavy metal adsorption and variable physical stability. Therefore, studies are being conducted of chemical cellulose modification in 


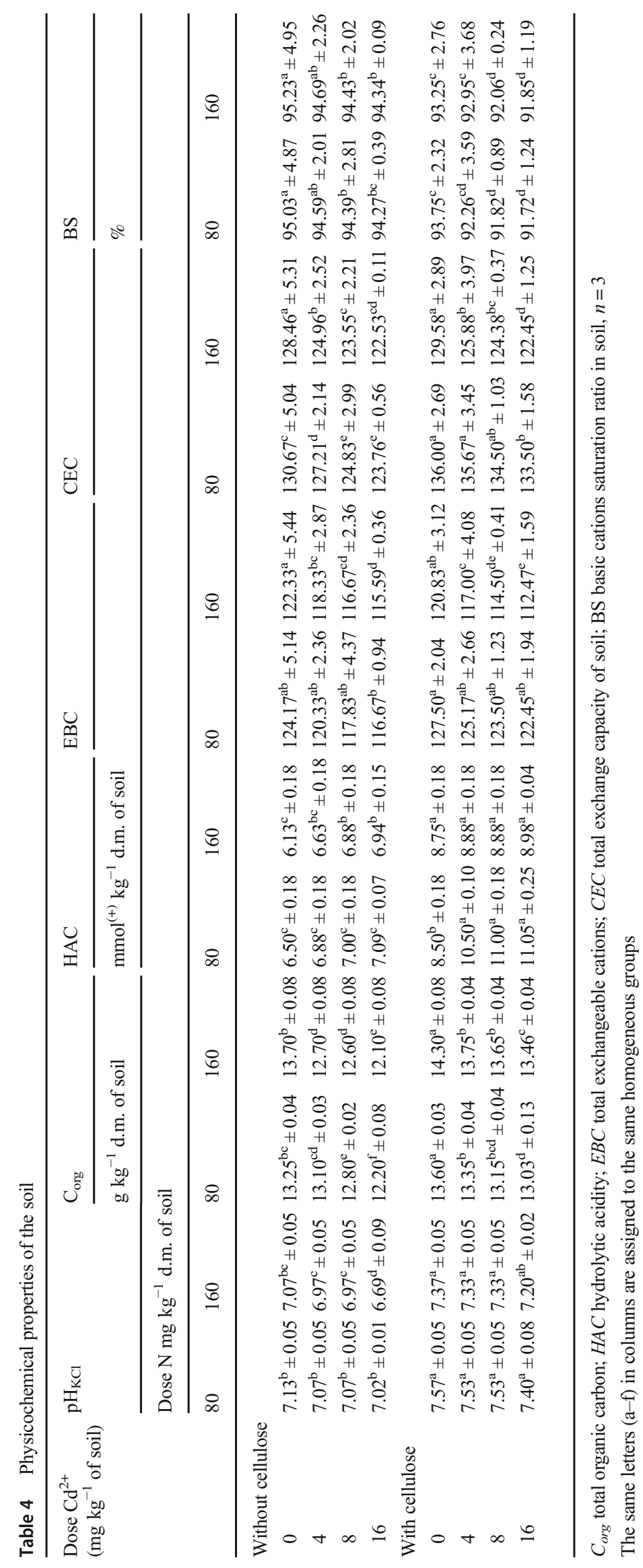


order to achieve sufficient structural strength and to make it better able to adsorb heavy metal ions. Higher yield of the above-ground parts and roots of white mustard and oats were observed in pots where nitrogen was applied at $160 \mathrm{mg} \mathrm{N} \mathrm{kg}^{-1}$ d.m. of soil. This may result from the fact that nitrogen is a nutrient needed by plants as a structural element of proteins and nucleic acids. Its presence is a condition of growth and development of crops, it stimulates growth of roots and the above-parts of plants, making them intensely green, i.e. it is the most important nutrient from a practical point of view (Hesse et al. 2004; Dubousset et al. 2009; Kaur et al. 2010; Carfagna et al. 2010; Gill et al. 2012).

\subsection{Biochemical, physical and chemical properties of the soil}

Biochemical activity of soil is very important for the proper functioning of soil ecosystems, whereby it is regarded as an appropriate indicator in estimating changes caused by soil contamination with heavy metals (Wu et al. 2010; Lombard et al. 2011; Kucharski et al. 2011). This study demonstrated a negative effect of cadmium on enzymatic activity of soil. Zaborowska et al. (2017) also noted an adverse effect of cadmium applied at 40 to $200 \mathrm{mg} \mathrm{kg}^{-1} \mathrm{~d}$.m. of soil on the activity of arylsulphatase, which deepened with an increasing level of soil contamination with $\mathrm{Cd}^{2+}$. A toxic effect of cadmium on individual enzymes was also demonstrated by Mikanova (2006) and Zaborowska et al. (2015). As in this study, arylsulphatase proved to be more sensitive to the presence of the metal under study than urease. According to the findings of a study by Wyszkowski and Wyszkowska (2009), soil contamination with cadmium decreased the activity of hydrolases, such as urease, acid phosphatase and alkaline phosphatase. Kavamura and Esposito (2010) demonstrated that the effect of heavy metals, including cadmium, on changes of soil enzyme activity is a result of disturbed function or denaturation of proteins or destruction of the microorganism cell membrane integrity. According to Gu and Yeung (2011), the toxic effect of $\mathrm{Cd}^{2+}$ on the enzyme structure and their effect changing the soil $\mathrm{pH}$ both reduces the enzyme-secreting microorganism count and decreases enzyme activity.

As Muhammad et al. (2012) reported, good parameter soils succumb to a lesser extent to the effect of stress factors, such as the presence of cadmium. The findings of this study confirm it. According to literature reports (Bolan et al. 2014; Stritsis et al. 2014; Li et al. 2016), the level of cadmium in a soil solution depends on the balance between processes of mobilisation and the immobilisation of metals. These processes are controlled by the physicochemical properties of soil (such as $\mathrm{pH}$, exchangeable cation capacity), activity and diversity of soil microorganisms, and the growth and development of plants.

\section{Conclusions}

White mustard and oats exhibited phytostabilisation potential towards cadmium-contaminated soil because the criterion (reducing cadmium transport from roots upwards) was met. White mustard and oats accumulated significantly larger amounts of $\mathrm{Cd}^{2+}$ in the roots than in the above-ground parts. Cellulose introduced to the soil and fertilisation with nitrogen alleviated the negative impact of cadmium on the growth and development of plants. The highest yield of the above-ground parts and roots of the plants was observed in pots where nitrogen was applied at $160 \mathrm{mg} \mathrm{N} \mathrm{kg}^{-1}$. Soil contamination with cadmium decreased the activity of all enzymes under study (dehydrogenases, catalase, urease, acid phosphatase, alkaline phosphatase, $\beta$-glucosidase, arylsulphatase). Excessive doses of cadmium decreased the soil $\mathrm{pH}$, total organic carbon, total exchangeable base cations, total cation exchange capacity of soil and soil saturation with base cations, whereas it increased the hydrolytic acidity.

Funding information Scientific research was financed by the Ministry of Science and Higher Education funds for statutory activity. This project was financially supported by the Minister of Science and Higher Education in the range of the program entitled 'Regional Initiative of Excellence' for the years 2019-2022, Project No. 010/RID/2018/19, amount of funding of 12,000,000 PLN.

\section{Compliance with ethical standards}

Conflict of interest The authors declare that they have no conflict of interest.

Open Access This article is distributed under the terms of the Creative Commons Attribution 4.0 International License (http:// creativecommons.org/licenses/by/4.0/), which permits unrestricted use, distribution, and reproduction in any medium, provided you give appropriate credit to the original author(s) and the source, provide a link to the Creative Commons license, and indicate if changes were made.

\section{References}

Aghababaei F, Raiesi F, Hosseinpur A (2014) The combined effects of earthworms and arbuscular mycorrhizalfungi on microbial biomass and enzyme activities in a calcareous soilspiked with cadmium. Appl Soil Ecol 75:33-42

Ali H, Khan E, Sajad MA (2013) Phytoremediation of heavy metalsconcepts and applications. Chemosphere 91:869-881

Bolan NB, Kunhikrishnan A, Thangarajana R, Kumpiened J, Parke J, Makinof T, Kirkhamg MB, Scheckelh K (2014) Remediation of heavy metal(loid) s contaminated soils - to mobilize or to immobilize? J Hazard Mater 266:141-166

Boros-Lajszner E, Wyszkowska J, Kucharski J (2018) Use of zeolite to neutralise nickel in a soil environment. Environ Monit Assess 190(1):54

Burns RG, DeForest JL, Marxsen J, Sinsabaugh RL, Stromberger ME, Wallenstein MD, Weintraub MN, Zoppini A (2013) Soil enzymes in 
a changing environment: current knowledge and future directions. Soil Biol Biochem 58:216-234

Carfagna S, Vona V, Martino VD, Esposito S, Riganoa C (2010) Nitrogen assimilation and cysteine biosynthesis in barley: evidence for root sulphurassimilationupon recovery from $\mathrm{N}$ deprivation. Environ Exp Bot 71:18-24

Cheraghi M, Lorestani B, Khorasani N, Yousef N, Karami M (2011) Findings on the phytoextraction and phytostabilization of soils contaminated with heavy metals. Biol Trace Elem Res 144(1-3):11331141

Dalvi A, Bhalerao S (2013) Response of plants towards heavy metal toxicity: an overview of avoidance, tolerance and uptake mechanism. Ann Plant Sci 2:362-368

Dubousset L, Abdallah M, Desfeux AS, Etienne P, Meuriot F, Hawkesford MJ, Gombert J, Ségura R, Bataillé MP, Rezé S, Bonnefoy J, Ameline AF, Ourry A, Le Dily F, Avice JC (2009) Remobilization of leaf S compounds and senescence inresponse to restricted sulphate supply during the vegetative stage of oilseedrape are affected by mineral $\mathrm{N}$ availability. J Exp Bot 60:3239-3253

Gill SS, Khan NA, Tuteja N (2012) Cadmium at high dose perturbs growth, photosynthesis and nitrogen metabolism while at low dose it up regulates sulfur assimilation and antioxidant machinery in garden cress (Lepidium sativum L.). Plant Sci 182:112-120

Gómez-Sagasti MT, Alkorta I, Becerril JM, Epelde L, Anza M, Garbisu C (2012) Microbial monitoring of the recovery of soil quality during heavy metal phytoremediation. Water Air Soil Pollut 223:3249 3262

Gu Y-Y, Yeung AT (2011) Desorption of cadmium from a natural Shanghai clay using citric acid industrial wastewater. J Hazard Mater 191:144-149. https://doi.org/10.1016/j.jhazmat.2011.04.054

Haddad SA, Lemanowicz J, Abd El-Azeim MM (2019) Cellulose decomposition in clay and sandy soils contaminated with heavy metals. Environ Sci Technol 16:3275-3290

Hashim MA, Mukhopadhyay S, Sahu JN, Sengupta B (2011) Remediation technologies for heavy metal contaminated groundwater. J Environ Manag 92:2355-2388

Hesse H, Nikiforova V, Gakiére B, Hoefgen R (2004) Molecular analysis and controlof cysteine biosynthesis: integration of nitrogen and Sulphur metabolism. J Exp Bot 55:1283-1292

Jabeen R, Ahmad A, Iqbal M (2009) Phytoremediation of heavy metals: physiological and molecular mechanisms. Bot Rev 75:339-364

Kabata-Pendias A, Mukherjee A (2007) Trace elements from soil to human. Springer-Verlag, Berlin, Heidelberg

Kaur G, Chandna R, Pandey R, Abrol YP, Iqbal M, Ahmad A (2010) Sulfur starvation and restoration affect nitrate uptake and assimilation in rapeseed. Protoplasma 248:299-311

Kavamura VN, Esposito E (2010) Biotechnological strategies applied to the decontamination of soils polluted with heavy metals. Biotechnol Adv 28:61-69

Knox AS, Seaman JC, Mench MJ, Vangronsveld J (2001) Remediation of metaland radionuclides- contaminated soils by in situ stabilization technics. In: Iskandar IK (ed) Environmental restoration of metalscontaminated soils. CRC Press LLC, Boca Raton, Florida, pp 21-60

Kucharski J, Wieczorek K, Wyszkowska J (2011) Changes in the enzymatic activity in sandy loam soil exposed to zinc pressure. J Elem 16(4):577-589

Li Z, Jia M, Christie P, Luo Y (2016) Changes in metals availability, desorption kinetics and speciation in contaminated soils during repeated phytoextraction with the $\mathrm{Zn} / \mathrm{Cd}$ hyperaccumulator Sedumplumbizincicola. Environ Pollut 209:123-131

Lombard N, Prestat E, van Elsas JD, Simonet P (2011) Soil-specific limitations for access and analysis of soil microbial communities by metagenomics. FEMS Microbiol Ecol 78:31-49

Lorenc-Plucińska G, Walentynowicz M, Niewiadomska A (2013) Capabilities of alders (Alnusincana and A. glutinosa) to grow in metal-contaminated soil. Ecol Eng 58:214-227
Masarovicova E, Kralova K, Kummerova M (2010) Principles of classification of medical plants as hyperaccumulators or excluders. Acta Physiol Plant 32(5):823-829

Masto RE, Chhonkar PK, Singh D, Patra AK (2008) Alternative soil quality indices for evaluating the effect of intensive cropping, fertilisation and manuring for 31 years in the semi-arid soils of India. Environ Monit Assess 136:419-435

McGrath SP, Zhao FJ (2003) Phytoextraction of metals and metalloids from contaminated soils. Curr Opin Biotechnol 14(3):277-282

Mench M, Lepp N, Bert V, Schwitzguébel JP, Gawronski SW, Schröder P, Vangronsveld J (2010) Successes and limitations of phytotechnologies at field scale: outcomes, assessment and outlook from COST Action 859. J Soils Sediments 10:1039-1070

Mikanova O (2006) Effect of heavy metals on some soil biological parameters. J Geochem Explor 88:220-223

Muhammad I, Puschenreiter M, Wenzel WW (2012) Cadmium and Zn availability as affected by $\mathrm{pH}$ manipulation and its assessment by soil extraction, DGT and indicator plants. B Environ Contam Tox 416:490-500

O'Connell DW, Birkinshaw C, O'Dwyer TF (2008) Heavy metal adsorbents prepared from the modification of cellulose: a review. Bioresour Technol 99:6709-6724

Padmavathiamma P, Li LY (2007) Phytoremediation technology: hyperaccumulation metals in plants. Water Air Soil Pollut 184: 105-126

Prica M, Dalmacija M, Dalmacija B, Pesic V, Krcmar D, Becelic M, Milosevic R (2012) Immobilization of cadmium from contaminated sediment using cardboard mill sludge. Arch Environ Prot 38(4): $109-118$

Rascio N, Navari-Izzo F (2011) Heavy metal hyperaccumulating plants: how and why do they do it? And what makes them so interesting? Plant Sci 180:169-181

Roccotiello E, Manfredi A, Drava G, Minganti V, Mariotti M, Berta G, Cornara L (2010) Zinc tolerance and accumulation in the ferns Polypodiumcambricum L. and Pterisvittata L. Ecotox Environ Safe 73:1264-1271

Sas-Nowosielska A, Kucharski R, Kuperberg JM, Japenga J, Pogrzeba M,Krzyżak J (2008) Phytoremediation technologies used to reduce environmental threatposed by metal-contaminated soils. Theory and reality. NATO Science Conference: 285-297, Wyd. Springer, ISBN 978-1-4020-8845-2

Satarug S, Garrett SH, Sens MA, Sens DA (2010) Cadmium, environmental exposure, and health outcomes. Environ Health Perspect 118:182-190

Schnoor JL (2000) Phytostabilization of metals using hybrid poplar trees. In: Raskin I, Ensley BD (eds) Phytoremediation of toxic metals: using plants to clean-up the environment. Wiley, New York, pp $133-150$

Statsoft, Inc, Statistica (2018) Data Analysis Software System, version 13.0. $<\mathrm{http} / /$ www.statsoft.com>

Stritsis C, Steingrobe B, Claassen N (2014) Cadmium fractions in an acid sandy soil and solution as affected by plant growth. J Soil Sci Plant Nutr 177:431-437

Sud D, Mahajan G, Kaur MP (2008) Agricultural waste material as potential adsorbent for sequestering heavy metal ions from aqueous solutions - a review. Bioresour Technol 99:6017-6027

Wu G, Kanga H, Zhang X, Shao H, Chu L, Ruand C (2010) A critical review on the bio-removal of hazardous heavy metals from contaminated soils: issues, progress, eco-environmental concerns and opportunities. $J$ Hazard Mater 174:1-8

Wyszkowski M, Wyszkowska J (2009) The effect of soil contamination with cadmium on the growth and chemical composition of spring Baley (Hordeum vulgare L.) and its relationship with the enzymatic activity of soil. Fresenius Environ Bull 18(7):1046-1053 
Yoon J, Cao X, Zhou Q, Ma LQ (2006) Accumulation of Pb, Cu and Zn in native plants growing on a contaminated Florida site. Sci Total Environ 368(2-3):456-464

Zaborowska M, Wyszkowska J, Kucharski J (2015) The possibilities of restoring the enzymatic balance of soil contaminated with cadmium. Int $J$ Environ Pollut 58(3):197-214

Zaborowska M, Kucharski J, Wyszkowska J (2017) Brown algae and basalt meal in maintaining the activity of arylsulfatase of soil polluted with cadmium. Water Air Soil Pollut 228(8):1-13

Zhang X, Xia H, Li Z, Zhung P, Gao B (2010) Potential of four grasses in remediation of $\mathrm{Cd}$ and $\mathrm{Zn}$ contaminated soils. Bioresour Technol 101:2063-2066
Zheng R, Li H, Jiang R, Römheld V, Zhang F, Zhao F-J (2011) The role of root hairs in cadmium acquisition by barley. Environ Pollut 159: 408-415

Zou T, Li, Zhang X, Yu H, Huang H (2012) Lead accumulation and phytostabilization potential of dominant plant species growing in a lead-zinc mine tailing. Environ Earth Sci 65:621-630

Publisher's note Springer Nature remains neutral with regard to jurisdictional claims in published maps and institutional affiliations. 